\title{
Runoff- and erosion-driven transport of cattle slurry: linking molecular tracers to hydrological processes
}

\author{
C. E. M. Lloyd ${ }^{1,2}$, K. Michaelides ${ }^{2}$, D. R. Chadwick ${ }^{3}$, J. A. J. Dungait ${ }^{4}$, and R. P. Evershed ${ }^{1}$ \\ ${ }^{1}$ Organic Geochemistry Unit, Bristol Biogeochemistry Research Centre, School of Chemistry, University of Bristol, \\ Cantocks Close, Bristol, BS8 1TS, UK \\ ${ }^{2}$ School of Geographical Sciences, University of Bristol, University Road, Bristol, BS8 1SS, UK \\ ${ }^{3}$ School of Environment, Natural Resources and Geography, Bangor University, Deiniol Road, Bangor, Gwynedd, \\ LL57 2UW, UK \\ ${ }^{4}$ Department of Sustainable Soils and Grassland Systems, Rothamsted Research-North Wyke, Okehampton, EX20 2SB, UK \\ Correspondence to: C. E. M. Lloyd (charlotte.lloyd@bristol.ac.uk)
}

Received: 13 July 2015 - Published in Biogeosciences Discuss.: 16 October 2015

Revised: 5 January 2016 - Accepted: 6 January 2016 - Published: 1 February 2016

\begin{abstract}
The addition of cattle slurry to agricultural land is a widespread practise, but if not correctly managed it can pose a contamination risk to aquatic ecosystems. The transport of inorganic and organic components of cattle slurry to watercourses is a major concern, yet little is known about the physical transport mechanisms and associated fluxes and timings of contamination threats. Therefore, the aim of the study was to ascertain the importance of flow pathway partitioning in the transport (fluxes and timing) of dissolved and particulate slurry-derived compounds with implications for off-site contamination. A series of rainfall-runoff and erosion experiments were carried out using the TRACE (Test Rig for Advancing Connectivity Experiments) experimental hillslope facility. The experiments allowed the quantification of the impact of changing slope gradient and rainfall intensity on nutrient transport from cattle slurry applied to the hillslope, via surface, subsurface, and vertical percolated flow pathways, as well as particulate transport from erosion. The dissolved components were traced using a combination of ammonium $\left(\mathrm{NH}_{4}^{+}\right)$and fluorescence analysis, while the particulate fraction was traced using organic biomarkers, $5 \beta$-stanols. Results showed that rainfall events which produced flashy hydrological responses, resulting in large quantities of surface runoff, were likely to move sediment and also flush dissolved components of slurry-derived material from the slope, increasing the contamination risk. Rainfall events which produced slower hydrological responses were dominated by vertical percolated flows removing less
\end{abstract}

sediment-associated material, but produced leachate which could contaminate deeper soil layers, and potentially groundwater, over a more prolonged period. Overall, this research provides new insights into the partitioning of slurry-derived material when applied to an unvegetated slope and the transport mechanisms by which contamination risks are created.

\section{Introduction}

Contamination of water bodies due to poor agricultural management is a global problem that affects aquatic ecosystems from individual catchments through to estuaries and oceans, and impacts human water supplies (e.g. Mitsch et al., 2001; Diaz and Rosenberg, 2008; Osterman et al., 2009; HELCOM, 2009). The ongoing introduction of legislation aimed at improving aquatic ecosystems (e.g. European Union Water Framework Directive) has focussed attention on efforts to decrease inputs of pollutants into surface and groundwater. Transport of inorganic and organic nutrients from livestock slurries to water courses are a particular concern, typically associated with over-application or poorly timed application of organic fertilisers to agricultural land (Dungait et al., 2012; Chadwick and Chen, 2003). The inorganic component of slurries (mainly nitrogen, $\mathrm{N}$ ) is generally considered as more soluble and directly bioavailable compared with the organic fraction, and specific forms such as nitrate are also more liable to immediate loss by leaching into water- 
courses (e.g. Chambers et al., 2000; Delconte et al., 2014; Quemada et al., 2013). However, studies have shown that the organic fraction can provide a large proportion of the total $\mathrm{N}$ load in some catchments and a smaller yet environmentally significant fraction in $\mathrm{N}$-enriched waters (Durand et al., 2011; Willett et al., 2004; Johnes and Burt, 1991). This excess $\mathrm{N}$ leads to eutrophication of surface waters, resulting in algal blooms and reduced oxygen levels. Sutton (2011) reported that excess $\mathrm{N}$ in the environment costs the EU between EUR 70 and 320 billion per annum, more than double the value that the $\mathrm{N}$ fertilisers provide to $\mathrm{EU}$ farms in terms of production. Combating and mitigating against these problems is extremely costly; the UK spends up to GBP 300 million each year cleaning water courses, equating to up to $2 \%$ of the gross agricultural output (Pretty et al., 2000). Given these severe environmental and financial consequences it is important to better understand the main transport pathways, fluxes and transit times of pollutants from livestock slurries into watercourses to develop effective mitigation strategies. Slurry transport has been quantified mainly in terms of the inorganic fraction (e.g. nitrate and phosphate) and associated pathogens (e.g. coliforms) (e.g. Edwards et al., 2012; Coelho et al., 2012; Eastman et al., 2010), but there is a relative lack of understanding of physical transport mechanisms and the associated fluxes and timings of contamination threats from areas treated with livestock slurries.

The transport of slurry components on land is primarily controlled by the hydrological and erosion regime operating at the site of application. The dynamics of flow pathway partitioning during storm events and the consequential output of agricultural contaminants has been explored (Delpla et al., 2011; Blanchard and Lerch, 2000; Gao et al., 2004; Zhang et al., 1997; Malone et al., 2004), but there is a lack of experimental data quantifying contaminant export via individual flow pathways due to methodological challenges. In a field context it is challenging to monitor multiple flow pathways without destructive sampling, although new research platforms are now making this type of research more possible (see Peukert et al. (2014) for an example). There are also challenges when choosing field sites that represent transport regimes across different slope angles or to account for other environmental variables. Therefore, laboratory flume experiments have been widely used to investigate questions relating to hydrology and erosion in conjunction with solute and sediment transport, although most studies to date have only measured surface runoff and/or vertical drainage (e.g. Montenegro et al., 2013; Guo et al., 2010; Aksoy et al., 2012; Asam et al., 2012). Our previous work using a one-dimensional soil column revealed the rapid partitioning of livestock slurries in the soil-water system into sediment-associated material remaining on or close to the surface and dissolved components which moved rapidly through the soil by leaching (Lloyd et al., 2012). Given this partitioning into surface and subsurface components and its potential importance for contamination of downstream aquatic and soil environments, we aim to quantify the relative fluxes of different slurry compounds driven by surface (overland flow and erosion) and subsurface (throughflow and leaching) flow pathways during a series of experiments in which rainfall rate and slope angle vary. We vary rainfall rate and slope angle in order to simulate hydrological variations which may result in differential partitioning of flow pathways.

In this study we use biogeochemical biomarker analysis in combination with controlled, large-scale rainfall-simulation experiments to quantify the relative fluxes of slurry components through different flow pathways within a slope system. In particular, we monitored flow rates in three pathways surface runoff, subsurface throughflow and vertical percolated - over the course of different rainfall simulation experiments in which we varied the slope gradient and rainfall intensity and duration. We also monitored erosion rates in the surface runoff component of the flow. Within samples of water discharging from each flow pathway we measured concentrations of ammonium $\left(\mathrm{NH}_{4}^{+}\right)$and the fluorescence spectra as tracers of the dissolved (soluble) component of the slurry. Samples of eroded sediment and in situ soil cores were analysed for total nitrogen (TN), carbon (TC) and $5 \beta$ stanols, which have been shown to be an effective and unequivocal biomarker of particulate slurry material (see Lloyd et al., 2012). The aim of the study was to ascertain the importance of flow pathway partitioning in the transport (fluxes and timing) of dissolved and particulate slurry-derived compounds with implications for off-site contamination.

\section{Materials and methods}

\subsection{Experimental set-up}

A series of rainfall-runoff and erosion experiments were carried out using TRACE (Test Rig for Advancing Connectivity Experiments) at the University of Bristol (described in detail in Michaelides et al., 2010). The experimental facility consists of a dual-axis soil slope measuring $6 \mathrm{~m} \times 2.5 \mathrm{~m}$, with a soil depth of $0.3 \mathrm{~m}$. The angle of the two soil containers was manipulated in order to simulate different slope gradients. Beneath the soil layer a wire mesh and geotextile layer separates the soil from a $2.5 \mathrm{~m}^{3}$ gravel layer. The slope was accompanied by a six-nozzle rainfall simulator fitted with full-cone nozzles (Lechler, Germany) and suspended $2.5 \mathrm{~m}$ above the soil to simulate different rainfall intensities. Water transported via surface, subsurface and vertical percolated pathways was monitored via four pairs of sampling outlets shown in Fig. 1. A series of four slurry-treated experiments were carried out varying combinations of slope angle (5 and $10^{\circ}$ ) and rainfall intensity $\left(60\right.$ and $120 \mathrm{~mm} \mathrm{~h}^{-1}$ ). The intensity and duration of the rainfall simulation were co-varied such that the total volume of rainfall applied was equal between experiments $\left(60 \mathrm{~mm} \mathrm{~h}^{-1}\right.$ for $100 \mathrm{~min}$ and $120 \mathrm{~mm} \mathrm{~h}^{-1}$ for $50 \mathrm{~min}$ ). The slope angles were chosen within a realis- 


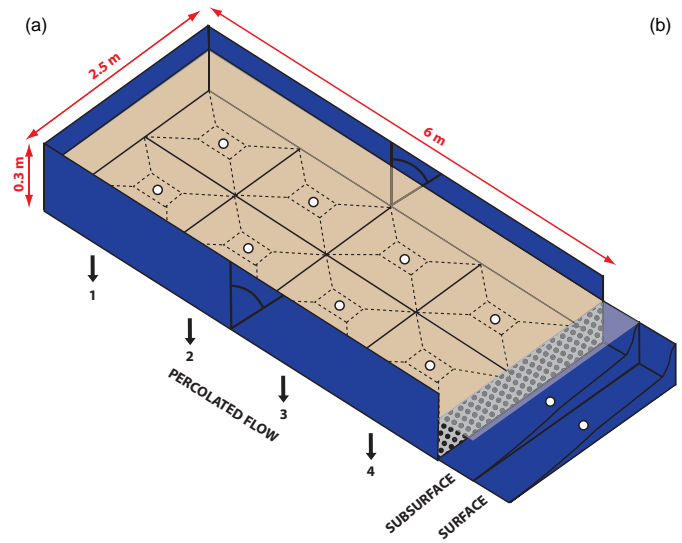

(b)

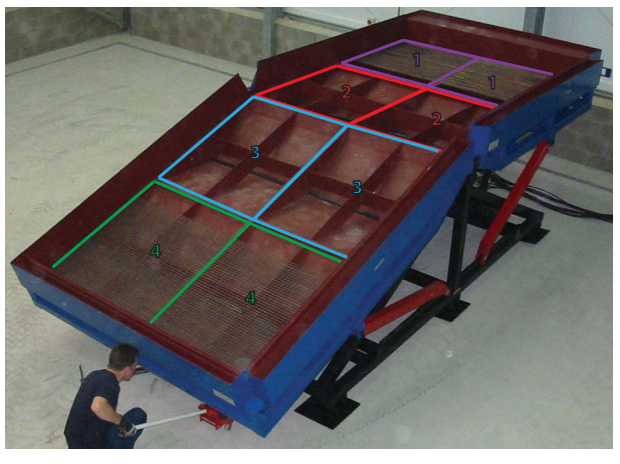

Figure 1. (a) Schematic showing sampling outlets on the TRACE slope and (b) photo showing the empty slope.

tic range found in agricultural settings. The rainfall intensities were chosen to test the impact of short duration, highintensity rainfall events on slurry transport because extreme storm events have a disproportional impact on the transport of dissolved and particulate contaminants to water courses (Evans and Johnes, 2004; Haygarth et al., 2005, 2012; Rozemeijer and Broers, 2007). Rainfall simulations using 60 and $120 \mathrm{~mm} \mathrm{~h}^{-1}$ were used so that a systematic doubling of rainfall intensity could be tested in conjunction with a change in slope gradient. $60 \mathrm{~mm} \mathrm{~h}^{-1}$ was chosen as this was the lowest intensity which could be stably simulated that was crucial for ensuring controlled experiments. Therefore we effectively substituted simulation time for intensity.

Before each experiment the slope was packed with the same silt loam soil ( $34 \%$ sand, $37 \%$ silt and $27 \%$ clay, $d_{50}=$ $200 \mu \mathrm{m})$ and compacted evenly across the surface of the slope. Even compaction was achieved for each experiment by following the method outlined in Michaelides et al. (2010), where layers of soil were added and compacted using a $2.5 \mathrm{~m}$ tamping board which was moved up and down the length of the slope. The average final bulk density achieved using this procedure was $\sim 1.5 \mathrm{~g} \mathrm{~cm}^{-3}$.

Cattle slurry collected from a commercial dairy farm was applied to the top $1 \mathrm{~m}$ of the experimental slope at an application rate of $5 \mathrm{~L} \mathrm{~m}^{-2}$ mimicking typical field application rates (CSF Evidence Team, 2011). Table 1 shows the chemical composition of the cattle slurry and the initial soil used for all of the experiments. Two additional control experiments with no slurry treatment were also carried out, one at each of the tested slope angles $\left(5\right.$ and $\left.10^{\circ}\right)$. Both of the control experiments were carried out using $60 \mathrm{~mm} \mathrm{~h}^{-1}$ rainfall intensity. During each experiment rainfall was applied and discharge from the slope was monitored via the three flow pathways: (1) surface runoff, (2) subsurface throughflow and (3) vertical percolated flow, in order to investigate the transport of slurryderived compounds. Eroded sediment was separated from the surface runoff using the protocol outlined below and kept for analysis. At the end of the rainfall simulation soil cores were
Table 1. Chemical characteristics of control soil and cattle slurry (dry weight basis) used in all of the experiments.

\begin{tabular}{lcc}
\hline Parameter & Initial soil & Cattle slurry \\
\hline Total carbon & $2.7 \% \pm 0.2$ & $39.6 \% \pm 0.3$ \\
Total organic carbon & $2.6 \% \pm 0.2$ & $39.0 \% \pm 0.3$ \\
Total nitrogen & $0.4 \% \pm 0.09$ & $3.49 \% \pm 0.004$ \\
Ammonium & $0.0016 \% \pm 0.0005$ & $0.39 \% \pm 0.0005$ \\
Nitrate & $0.0022 \% \pm 0.00006$ & $0 \%$ \\
Nitrite & $0.00004 \% \pm 0.00003$ & $0 \%$ \\
Organic N & $0.4 \% \pm 0.09$ & $3.45 \% \pm 0.004$ \\
\hline
\end{tabular}

taken from the slope according to the sampling strategy outlined in Sect. 2.2. The soil cores and eroded sediment were used to investigate the erosion and within-slope deposition of slurry-derived particulates.

\subsection{Sampling}

Discharge from each flow pathway was determined at regular intervals during the course of the rainfall simulations. Discharge from the surface runoff pathway was monitored by logging water depth using a "V"-notch weir and capacitance depth probe, at $1 \mathrm{~min}$ intervals. The water depth was converted to discharge by a pre-calibrated stage-discharge relationship for the "V"-notch weir. Additional manual samples of the surface runoff were taken at $\sim 5 \mathrm{~min}$ intervals to determine sediment concentration and to obtain eroded sediment samples for analysis. The water and sediment were separated using a centrifuge ( $2400 \mathrm{rpm}, 30 \mathrm{~min}$ ) and the water samples were filtered through $0.45 \mu \mathrm{m}$ filter (Whatman, cellulose acetate) then stored at $-18^{\circ} \mathrm{C}$ until analysis was carried out. Flow discharge from the subsurface and percolated pathways was monitored manually at $\sim 5 \mathrm{~min}$ intervals by timing the flow of a known volume of water.

At the end of the rainfall simulations, 18 soil cores were taken over a regularly spaced $3 \times 6$ sample grid leaving a buffer of $0.5 \mathrm{~m}$ around the slope perimeter to avoid edge ef- 
fects (samples $0.75 \mathrm{~m}$ apart across slope, $1 \mathrm{~m}$ apart downslope), to a depth of $5 \mathrm{~cm}$. Only the top $5 \mathrm{~cm}$ were sampled because pilot experiments and previous research have shown that this section is the most important in terms of the transport of slurry-derived material (see Lloyd et al., 2012). The soil cores and eroded sediment were freeze-dried and stored at $-18^{\circ} \mathrm{C}$ until analysis.

\subsection{Laboratory analyses}

\subsubsection{Runoff water analyses}

All water samples were analysed for $\mathrm{NH}_{4}^{+}\left(\mu \mathrm{gL}^{-1}\right)$ using a continuous segmented flow autoanalyser (AA3; Seal Analytical). $\mathrm{NH}_{4}^{+}$was determined using the Berthelot reaction (Berthelot, 1859), where a blue-green compound was produced and quantified colorimetrically. $\mathrm{NH}_{4}^{+}$was the only inorganic $\mathrm{N}$ fraction measured as the cattle slurry used contained no measureable $\mathrm{NO}_{3}^{-}$or $\mathrm{NO}_{2}^{-}$(see Table 1). Also, previous work carried out using the same soil and slurry showed that after slurry application and leaching for $8 \mathrm{~h}$, there was no detectable difference between the concentrations of extractable $\mathrm{NO}_{3}^{-}$or $\mathrm{NO}_{2}^{-}$from slurry-treated or control soils (unpublished data). This is most probably due to the soils having a low moisture content $(\sim 8 \%)$ at the beginning of the experiments, which then become rapidly saturated. Both low moisture and potential oxygen limitation (due to waterlogging) later in the experiments could inhibit rates of nitrification. As a result, there is no evidence to suggest that nitrification would occur over the timescales of the current TRACE experiments and therefore $\mathrm{NH}_{4}^{+}$was the sole inorganic compound used to trace slurry in this paper.

Fluorescence spectroscopic analysis of all leachate samples was carried out using a HORIBA Jobin Yvon FluoroLog ${ }^{\circledR}-3$ spectrofluorometer (Stanmore, UK); the excitation source was a Xe lamp. Samples were measured in a $1 \mathrm{~cm}$ quartz cuvette at room temperature. The methodology of Peuravuori et al. (2002) was adopted to collect synchronous spectra, using $1 \mathrm{~nm}$ increments from 250 to $600 \mathrm{~nm}$, with an $18 \mathrm{~nm}$ offset between the excitation and emission monochromators. The spectra were then corrected for the fluorescence of Milli-Q water and for inner-filter effects, based on the sample absorbance. The sample absorbance at 250$600 \mathrm{~nm}$ was measured in a $1 \mathrm{~cm}$ cuvette, using a Shimadzu UVmini-1240. Milli-Q subtracted absorbance spectra were then used to correct the fluorescence spectra for primary and secondary inner-filter effects using the following equation:

$I_{\mathrm{c}}=I_{\mathrm{m}} /\left(10^{-b\left(A_{\mathrm{ex}}+A_{\mathrm{em}}\right)}\right)$,

where $I_{\mathrm{c}}$ is the true fluorescence intensity, $I_{\mathrm{m}}$ is the measured fluorescence intensity, $b$ is the sample path length, and $A_{\text {ex }}$ and $A_{\text {em }}$ are the absorbance values at the excitation and emission wavelengths respectively (Lakowicz, 1983; Ohno, 2002). The spectra were then converted to arbitrary Raman units by normalising the fluorescence intensities by the area of the water Raman peak in order to compare the relative magnitude of the peaks present between the experiments. The ratio between the fluorescence intensities of emissions at $\sim 290$ and $\sim 380 \mathrm{~nm}$ was calculated as previous work has shown that it can be used to monitor the presence of slurry-derived compounds in natural waters (Baker, 2002a, b; Naden et al., 2010; Lloyd et al., 2012).

\subsubsection{Soil and eroded sediment analyses}

The soil and eroded sediment samples were analysed in triplicate for total carbon (TC), inorganic carbon (IC) and total nitrogen (TN) (\%) using a Carlo Erba EA1108 Elemental Analyser. Total organic carbon (TOC) was then calculated by subtracting the IC from the TC.

Lipid analysis was used to extract and quantify the stanol concentration within the soil cores and eroded sediment samples, specifically the $5 \beta$-stanols, which were used as a tracer of slurry-derived particulates (Bull et al., 2002; Leeming et al., 1996; Evershed et al., 1997; Nash et al., 2005; Lloyd et al., 2012). As $5 \beta$-stanols stigmastanol and its epimer are the biohydrogenation products of sitosterol (a major plant sterol) and are only produced during rumination, they can be used as unequivocal tracers of the hydrophobic fraction of ruminant faeces. The $5 \alpha$ form is produced by microbial activity under aerobic conditions, i.e. outside the rumen, so the ratio $5 \beta: 5 \alpha$ is used to investigate the contribution of either source. To achieve this, a total lipid extract (TLE) was obtained from the soil and eroded sediment samples using Soxhlet extraction $\left(\mathrm{CH}_{2} \mathrm{Cl}_{2}: \mathrm{Me}_{2} \mathrm{CO} 9: 1 v / v, 24 \mathrm{~h}\right.$, van Bergen et al., 1997) with an internal standard (preg-5-en-3 $\beta$-ol). Aliquots of the TLE samples were saponified by adding $1 \mathrm{~mL}$ of $0.5 \mathrm{M}$ methylated $\mathrm{MeOH}$ and heating at $70^{\circ} \mathrm{C}$ for $60 \mathrm{~min}$ before acidification to $\mathrm{pH} 3$ by adding $1 \mathrm{~mL}$ of $1 \mathrm{M} \mathrm{HCl}$. Then $1 \mathrm{~mL}$ of DCM-extracted DDW was added along with $2 \mathrm{~mL}$ of DCM and the sample was vortex mixed for $20 \mathrm{~s}$ and allowed to settle to give a two-phase sample. The organic layer was extracted from the bottom then the DCM extraction was repeated two more times to ensure the entire organic sample was collected. The composite organic phase was then filtered through a pipette containing anhydrous sodium sulphate $\left(\mathrm{NaSO}_{4}\right)$ in order to ensure any residual water was removed, then the sample was blown down to dryness under $\mathrm{N}_{2}$. An aliquot of the saponified TLE was then derivatised using $50 \mu \mathrm{L}$ of N,O-bis(trimethylsilyl)trifluroacetamide with $1 \%$ trimethylchlorosilane and heating at $70^{\circ} \mathrm{C}$ for $1 \mathrm{~h}$. The samples were then analysed using a Finnigan TRACE GC/MS by injecting $1 \mu \mathrm{L}$ on-column, using a HP-1 $(50 \mathrm{~m}, 0.32 \mathrm{~mm}$, $0.17 \mu \mathrm{m})$ column. The GC temperature programme was $50{ }^{\circ} \mathrm{C}(2 \mathrm{~min})$, ramping to $245^{\circ} \mathrm{C}$ at a rate of $15^{\circ} \mathrm{C} \mathrm{min}{ }^{-1}$, then increasing to $250^{\circ} \mathrm{C}$ at a rate of $0.5^{\circ} \mathrm{C} \mathrm{min}^{-1}$ followed by a ramp to $300^{\circ} \mathrm{C}$ at a rate of $6^{\circ} \mathrm{C} \mathrm{min}{ }^{-1}$, then finally held for $20 \mathrm{~min}$. This $\mathrm{GC}$ temperature programme was chosen to maximise the information gained at the time period where the stanols elute. The mass spectrometer was operated at 
$70 \mathrm{eV}$ with the quadrapole mass analyser scanning the range $\mathrm{m} / \mathrm{z}$ 50-650 (scan time $0.6 \mathrm{~s}$ ). The distribution of sterols and stanols present were then quantified against the internal standard.

The ratio of $5 \beta-: 5 \alpha$-stanols was determined in order to assess the relative contribution of slurry-derived insoluble organic matter (IOM) to native soil IOM in the soil cores. This is a useful technique where the $5 \beta$-stanol concentrations are low, as the ratio allows differences between the samples to be seen more clearly.

\subsection{Statistical analyses}

Statistical differences between the slurry-treated experiments and the control experiments were tested for each of the measured parameters using either a $t$ test or a Mann-Whitney test depending on whether the specific data sets were normally or non-normally distributed.

\section{Results}

\subsection{Flow pathway partitioning and erosion}

The results show that as rainfall intensity and slope gradient increased a higher proportion of flow was transported via surface and shallow subsurface flows in the slurry-treated experiments (Fig. 2). Doubling the rainfall intensity had a larger impact on the flow pathway partitioning compared with doubling the slope gradient. Figure 2 summarises the partitioning of water flow through the slope for the slurry-treated experiments. Discharge data for the control experiments are not included as the results mirrored the slurry experiments run under the same experimental conditions. The two experimental end-member scenarios showed a reversal in behaviour of the flow partitioning, where at $5^{\circ}, 60 \mathrm{mmh}^{-1} \sim 99 \%$ of the flow was transported as vertical percolated flow and at $10^{\circ}$, $120 \mathrm{~mm} \mathrm{~h}^{-1}, \sim 99 \%$ of the flow was routed across the soil surface as overland flow. All experiments received the same volume of rainfall, therefore halving the slope gradient and rainfall intensity caused a $60 \%$ increase in the storage of water within the soil. At a rainfall intensity of $60 \mathrm{~mm} \mathrm{~h}^{-1}$ doubling the slope gradient induced a reduction in the vertical percolated flow (to $26 \%$ ) and increase in subsurface throughflow $(28 \%)$ and surface runoff $(46 \%)$ due to higher surface water velocities and reduced infiltration rates. Therefore, overland flow generation was a combination of infiltrationexcess (fast) and saturation excess (slower) overland flow. When the rainfall intensity increased to $120 \mathrm{~mm} \mathrm{~h}^{-1}$ the system was dominated by infiltration-excess overland flow. At a slope gradient of $5^{\circ}, 67 \%$ of the discharge was surface runoff and $29 \%$ was subsurface throughflow. However, increasing the slope gradient to $10^{\circ}$ resulted in $99 \%$ of the flow transported as surface runoff.

Figure 3 shows the corresponding sedigraphs of eroded sediment transported in the overland flow for each of the

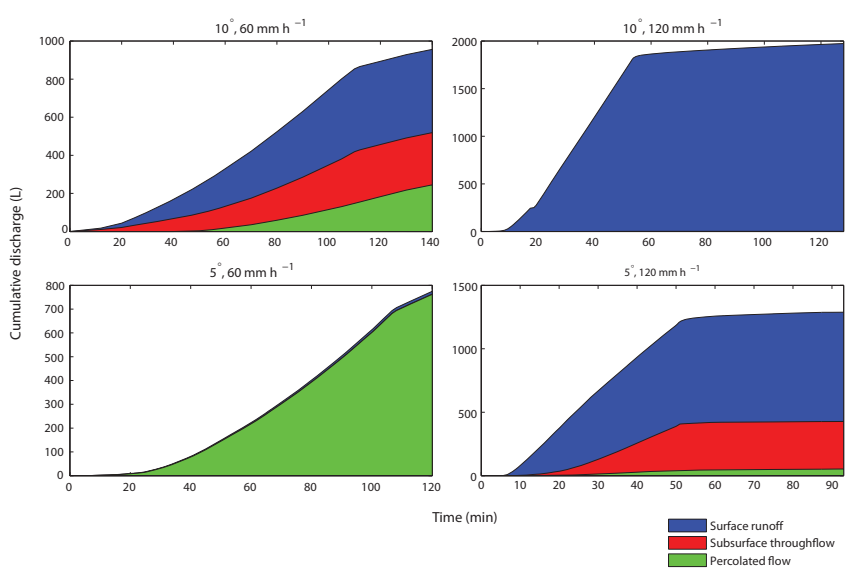

Figure 2. Plots showing cumulative discharge from surface runoff, subsurface throughflow and vertical percolated flow from the slurrytreated slope experiments.

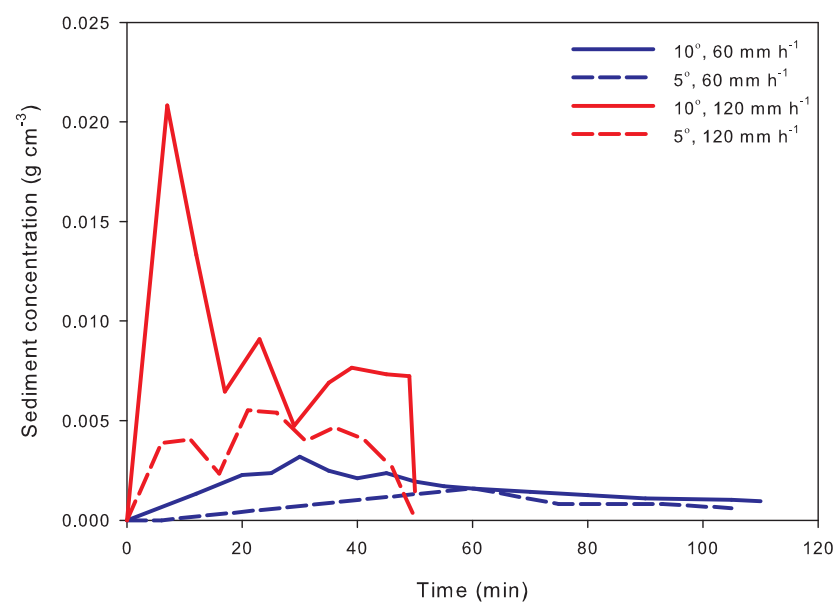

Figure 3. Plot showing sedigraphs for each of the slurry-treated slope experiments.

slurry-treated experiments. Like discharge the data for the control experiments are not included as their behaviour mirrored that of the slurry-treated experiment run under the same experimental conditions. The experiments run at $60 \mathrm{~mm} \mathrm{~h}^{-1}$ rainfall produced sediment concentrations that increased gradually until the middle of the experiment before decreasing later in the event. At $120 \mathrm{~mm} \mathrm{~h}^{-1}$ the $5^{\circ}$ experiment produced a similar trend to those run at the lower rainfall intensity (at both 5 and $10^{\circ}$ slopes), however the sediment discharges were generally higher. When the slope gradient increased to $10^{\circ}$ the shape of the sedigraph changed and the greatest sediment concentrations were at the beginning of the rainfall simulations. This suggests that rainsplash, combined with higher water velocities and higher flow shear stress expected at steeper gradients, could initially rapidly move a large quantity of sediment, after which the system slowed 

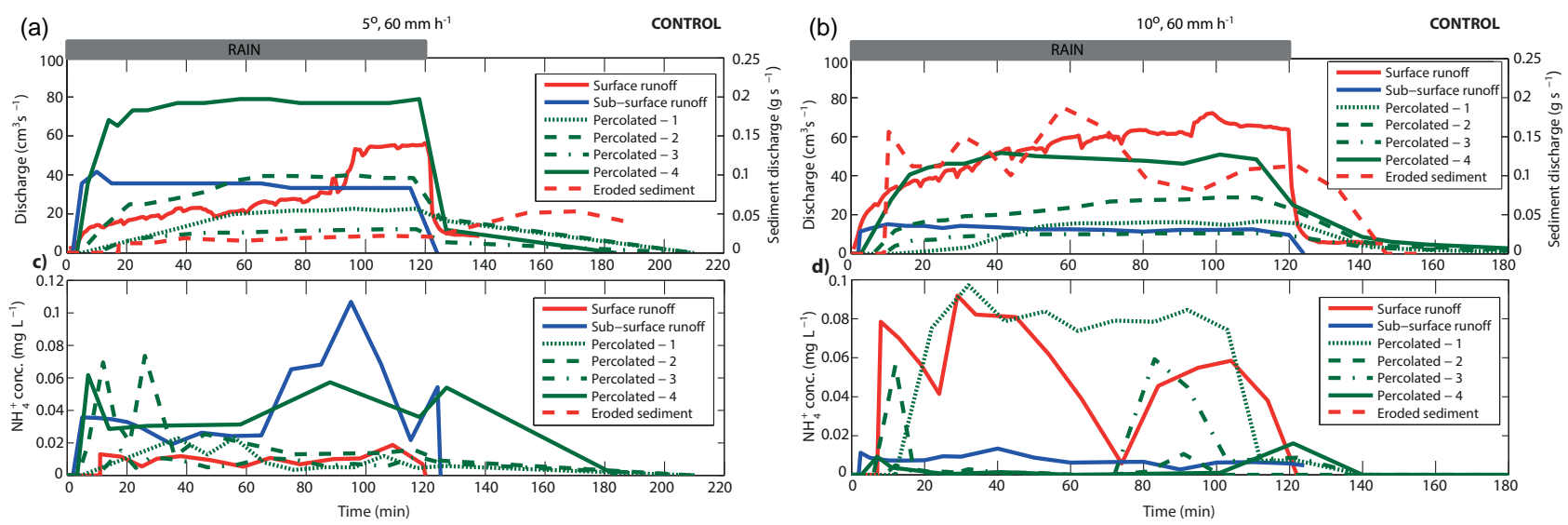

Figure 4. Plots showing water and sediment discharge $(\mathbf{a}, \mathbf{b})$ and $\mathrm{NH}_{4}^{+}$concentrations $(\mathbf{c}, \mathbf{d})$ from each monitored flow pathway for the control experiments (no slurry) at two slope angles $\left(5\right.$ and $\left.10^{\circ}\right)$ at $60 \mathrm{~mm} \mathrm{~h}^{-1}$ rainfall intensity. Where percolated $1-4$ represent vertical transport from each of the pairs of tanks beneath the soil slope as marked in Fig. 1.
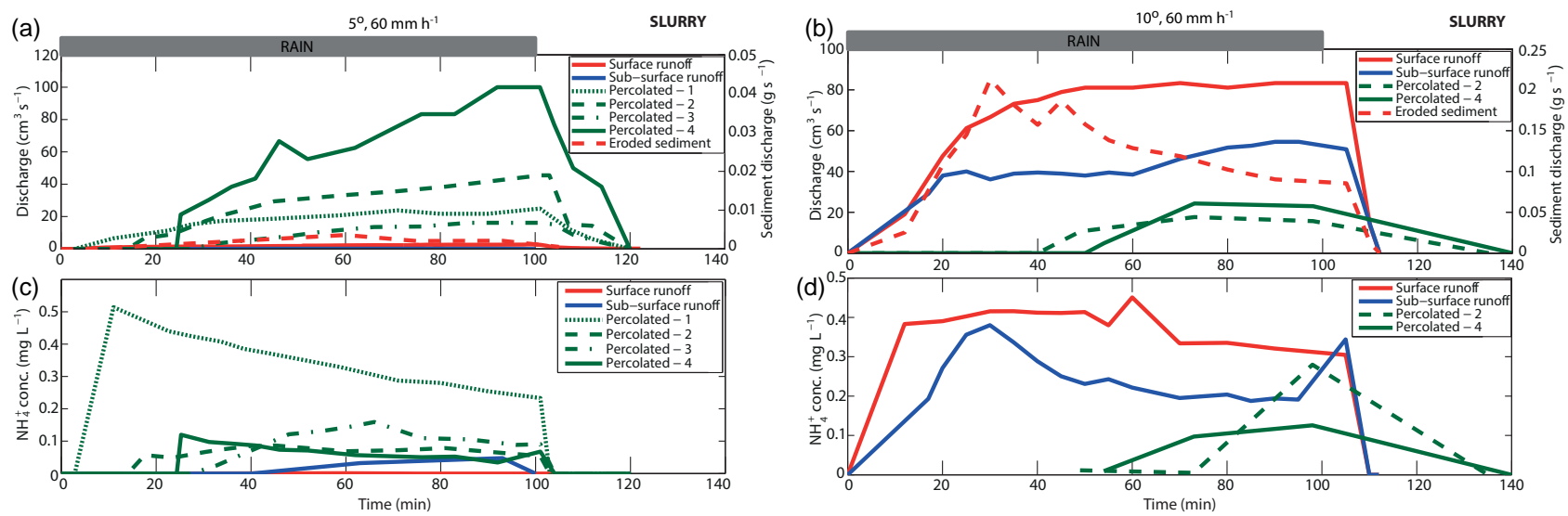

Figure 5. Plots showing water and sediment discharge (a, b) and $\mathrm{NH}_{4}^{+}$concentrations (c, d) from each monitored flow pathway for the slurry-treated experiments at two slope angles $\left(5\right.$ and $\left.10^{\circ}\right)$ at $60 \mathrm{~mm} \mathrm{~h}^{-1}$ rainfall intensity. Where percolated 1-4 represent vertical transport from each of the pairs of tanks beneath the soil slope as marked in Fig. 1. Note: data which are absent reflect the lack of activation of a particular flow pathway.

to a sediment export rate similar to that of the lower gradient slope.

\subsection{Dissolved chemical species analyses}

\subsubsection{Ammonium $\left(\mathrm{NH}_{4}^{+}\right)$}

Figures 4, 5, and 6 show a direct comparison of the flow and sediment and the $\mathrm{NH}_{4}^{+}$concentration from each monitored flow pathway during each experiment. The control experiments (Fig. 4) produced a total of between 12 and $25 \mathrm{mg}$ of leached $\mathrm{NH}_{4}^{+}$originating from the soil (no added slurry), with concentrations never exceeding $0.1 \mathrm{mgL}^{-1}$ from any pathway. The total mass of $\mathrm{NH}_{4}^{+}$exported from each experiment depended on the relative flow pathway partitioning because the experiments which generated higher volumes of surface runoff contributed a larger flux of $\mathrm{NH}_{4}^{+}$, between 1.8 and $11.3 \%$ of the total $\mathrm{NH}_{4}^{+}$measured from the slope outlets. An approximately equal proportion of the exported $\mathrm{NH}_{4}^{+}$was leached from the vertical percolated flow outlets in all control experiments, between $10.9 \mathrm{mg}(48 \%)$ and $7.6 \mathrm{mg}(62 \%)$, with the remainder transported via sub-surface runoff.

The addition of slurry to the slope caused a marked increase in the export of $\mathrm{NH}_{4}^{+}$compared to the controls, in some cases by an order of magnitude, indicating that the main source of $\mathrm{NH}_{4}^{+}$leached from the slope was the added slurry. The $\mathrm{NH}_{4}^{+}$concentrations from the slurrytreated experiments were significantly higher than those from the control experiments (Mann-Whitney, control vs. slurry, $p \leq 0.001$ ). As with the control experiments, total $\mathrm{NH}_{4}^{+}$export was affected by the flow pathway partitioning. The slurry-treated experiments which were dominated by surface runoff exhibited the largest export of $\mathrm{NH}_{4}^{+}$, between 66 

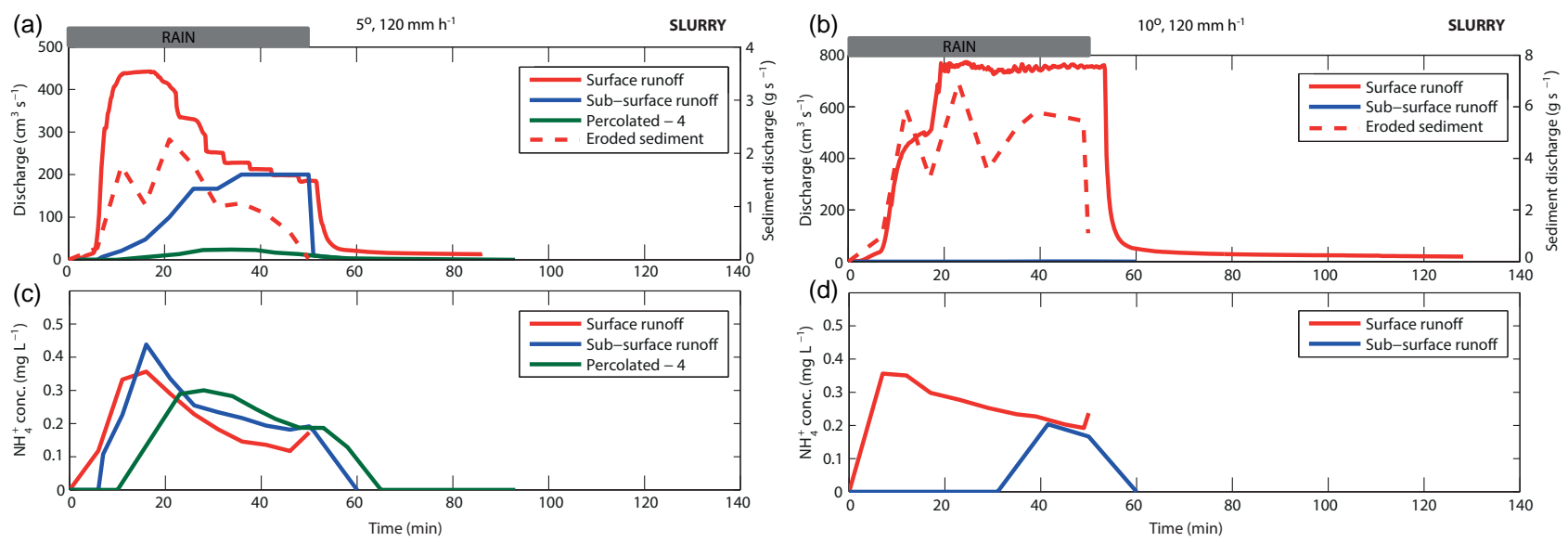

Figure 6. Plots showing water and sediment discharge $(\mathbf{a}, \mathbf{b})$ and $\mathrm{NH}_{4}^{+}$concentrations $(\mathbf{c}, \mathbf{d})$ from each monitored flow pathway for the slurry-treated experiments at two slope angles $\left(5\right.$ and $\left.10^{\circ}\right)$ at $120 \mathrm{~mm} \mathrm{~h}^{-1}$ rainfall intensity. Where percolated $1-4$ represent vertical transport from each of the pairs of tanks beneath the soil slope as marked in Fig. 1. Note: data which are absent reflect the lack of activation of a particular flow pathway.

and $99 \%$ of the total. The experiment with the most surface runoff $\left(10^{\circ}, 120 \mathrm{~mm} \mathrm{~h}^{-1}\right)$ generated a $\mathrm{NH}_{4}^{+}$yield of $404 \mathrm{mg}$, an order of magnitude larger than any other experiment. $\mathrm{NH}_{4}^{+}$was also observed at similar concentrations in the sub-surface flow pathway when activated. During the experiment where the majority of the water flow was via vertically percolated pathways $\left(5^{\circ}, 60 \mathrm{~mm} \mathrm{~h}^{-1}\right)$, the concentrations of $\mathrm{NH}_{4}^{+}$were similar to those observed in the dominant pathways for other slurry experiments $\left(0.1-0.5 \mathrm{mgL}^{-1}\right)$. The area associated with the largest percolated flux tended to be the top of the slope directly below the slurry application area, illustrating that the slurry can still be rapidly transported during smaller rainfall events but the dissolved fraction is infiltrated rather than routed across the soil surface.

In general, the transport of $\mathrm{NH}_{4}^{+}$was controlled by the flow partitioning, and the concentrations did not increase with contact time with the soil, providing additional evidence that the $\mathrm{NH}_{4}^{+}$was representing the dissolved slurry-derived material. This can be seen very clearly in Fig. $6 c$, where the concentration of $\mathrm{NH}_{4}^{+}$observed in the percolated flow pathway is highest after $20 \mathrm{~min}$, showing that the slurry material had reached the bottom of the slope.

\subsubsection{Fluorescence spectroscopy}

Figure 7 shows the average fluorescence spectra for each flow pathway for each experiment, along with the mean spectra of the control samples and the slurry. This plot highlights that the difference between the fluorescence spectra of the slurry and control soil is the magnitude of the peak at excitation wavelength $270 \mathrm{~nm}$ (emission $290 \mathrm{~nm}$ ), which has been attributed to "proteinaceous material" (Baker, 2002a, b; Peuravuori et al., 2002), therefore providing a useful tracer of slurry-derived dissolved organic matter (DOM) (Lloyd et al., 2012). This "protein" fluorescence can be a useful tracer for slurry as proteins form a significant part of the organic nitrogen pool, which can be derived from plant, animal or bacterial sources (Jones et al., 2005; Vinolas et al., 2001). It is well documented that fluorescence at an excitation at $270 \mathrm{~nm}$ can be linked to farm wastes (Baker, 2002a; Hudson et al., 2007; Naden et al., 2010) and the lack of a signal in the control samples supports the hypothesis that the slurry is the source in these experiments. The assumed higher molecular weight compounds that fluoresce at longer wavelengths are most likely derived from soil DOM rather than from the slurry. In general, the fluorescence intensity at higher wavelengths (e.g. 360 and $446 \mathrm{~nm}$ ) is lower in the surface runoff and subsurface samples compared with those collected from the percolated pathway, providing more evidence that the source is soil-derived.

The ratio between the fluorescence intensities at excitation at 270 and $360 \mathrm{~nm}$ can be used to monitor the presence of slurry-derived DOM in natural waters (Baker, 2002a, b; Naden et al., 2010; Lloyd et al., 2012). Figure 8 shows the change in the $270: 360$ ratio through time for each flow outlet for each of the slurry-treated experiments. The average ratio of the control samples was 0.044 with a standard deviation of 0.019 , while the slurry had a ratio of 1.72 . The slurry-treated water samples had a large variability in ratios with a range of $0.025-0.32$. The slurry-treated water samples collected from the surface runoff and the subsurface throughflow consistently displayed ratios significantly higher than those from the control slopes (Surface runoff, Mann Whitney, control vs. slurry, $p=<0.001$; subsurface, $t$ test, control vs. slurry, $p=<0.001$ ) suggesting that slurry-derived DOM was being transported by those flow pathways. The data from the vertical percolated flow pathways were recorded for each of the four paired outlets (see Fig. 1 for locations) so that the spatial distribution of slurry-derived DOM transport could 

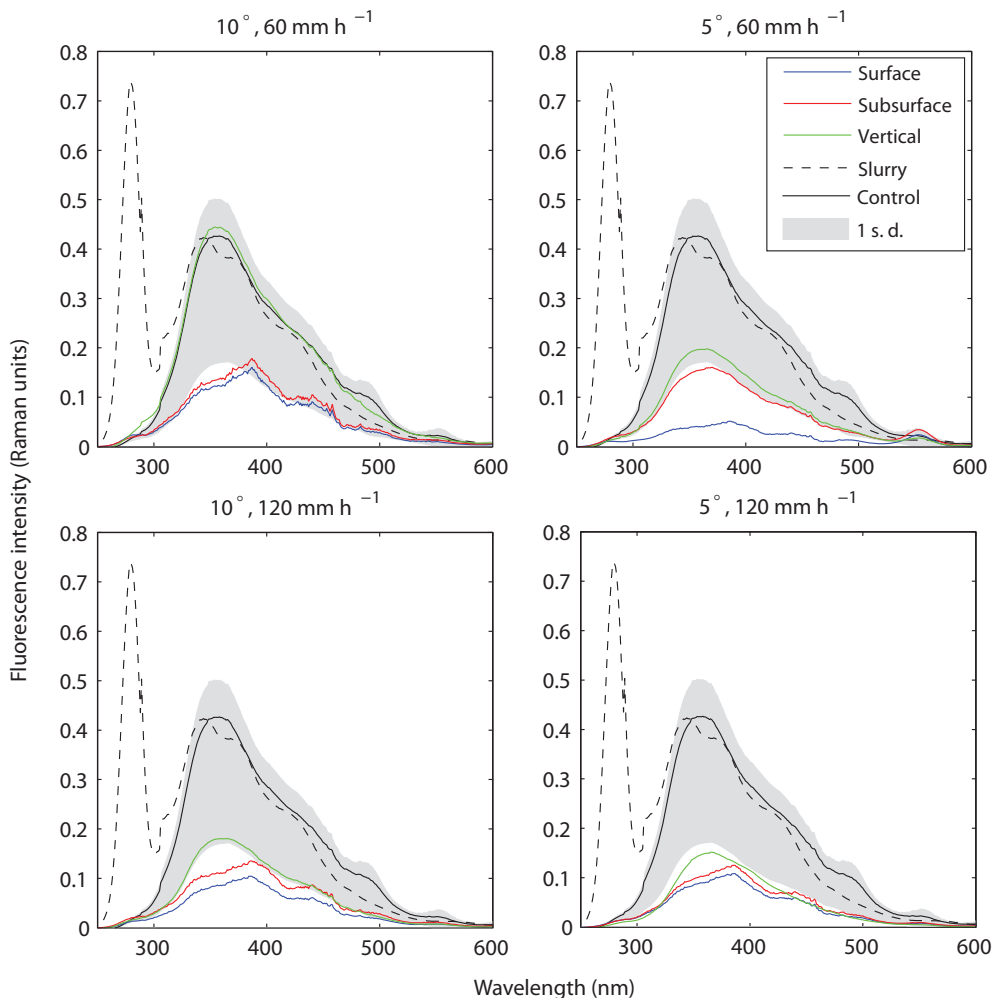

Figure 7. Plots showing the mean fluorescence spectra from the surface runoff, subsurface throughflow and vertical percolated pathways for each slurry-treated experiment along with the average spectra from all pathways of the control experiments and the spectra from the applied slurry. The shaded area represents 1 standard deviation around the mean of the control soil spectra.
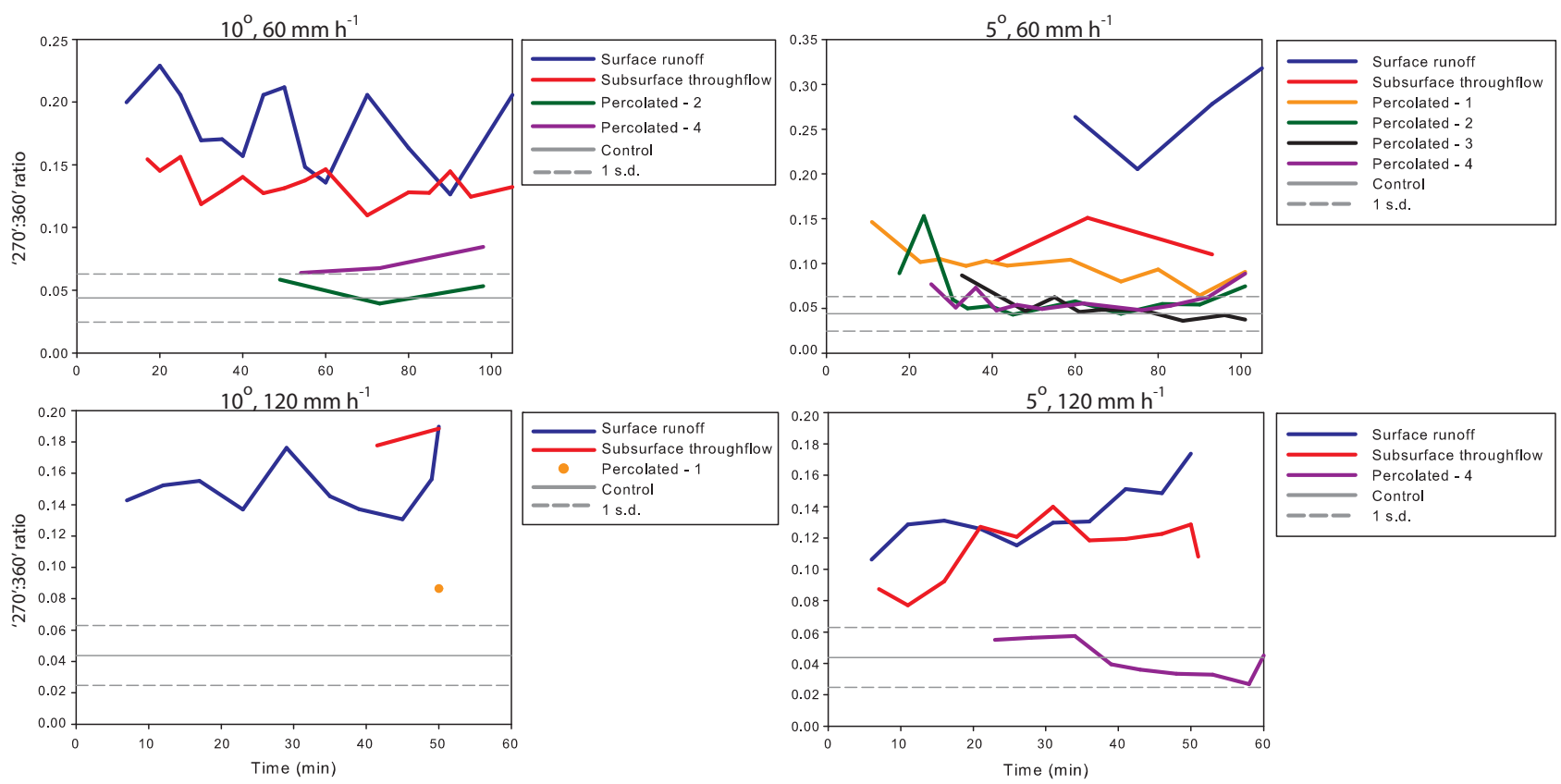

Figure 8. Plots showing the ratio of $270: 360 \mathrm{~nm}$ fluorescence intensities for each measured flow pathway. The grey lines represent the average value for the control samples and the grey dashed lines are 1 standard deviation around the mean. 
be examined. At the highest slope gradient and rainfall intensity slurry-derived DOM was only detected in percolated outlet 1 which is located directly underneath the slurry application area, there was a lack of infiltration across the rest of the slope. The experiment run with a slope gradient of $5^{\circ}$ and rainfall intensity of $60 \mathrm{~mm} \mathrm{~h}^{-1}$ produced the highest volume of discharge from vertical percolated flow, however slurry-derived DOM was only significantly detected (MannWhitney, control vs. slurry, $p=<0.001$ ) via the fluorescence in outlet 1 throughout the experiment and through outlet 2 for the first $30 \mathrm{~min}$. The $270: 360$ ratio was also significantly greater than the control values in outlets 1,2 , and 4 (MannWhitney, control vs. slurry, $p=<0.001$ ) at the end of the experiment suggesting slurry-derived DOM was reaching the bottom of the slope by the end of the simulation. There were no significant increases in $270: 360 \mathrm{~nm}$ fluorescence from any of the vertical percolated flow pathways in the experiment run at $5^{\circ}$ and $120 \mathrm{~mm} \mathrm{~h}^{-1}$ rainfall, or from the base of the slope (outlet 4 ) in the $10^{\circ}, 60 \mathrm{~mm} \mathrm{~h}^{-1}$ experiment. Overall, these analyses allowed the identification of the locations where slurry-derived DOM has been transported throughout the rainfall simulations.

\subsection{Soil and eroded-sediment analyses}

\subsubsection{Elemental analyses of $\mathrm{C}$ and $\mathrm{N}$}

Our previous work showed that the components of slurryderived material which are most likely to bind to the soil remain in the top $5 \mathrm{~cm}$ even after prolonged periods of leaching (Lloyd et al., 2012). Therefore, elemental analyses of $\mathrm{C}$ and $\mathrm{N}$ were restricted to the top $5 \mathrm{~cm}$ of the soil cores. There was no significant difference between the TOC and $\mathrm{TN}$ values in the soil cores for the slurry-treated experiments (median $\mathrm{TOC}=1.7 \%, \mathrm{TN}=0.2 \%$ ) compared to the experimental controls (median $\mathrm{TOC}=1.4 \%, \mathrm{TN}=0.3 \%)(\mathrm{TOC}$, Mann-Whitney, control vs. slurry, $p=0.052$; TN, Mann Whitney, control vs. slurry, $p=0.181)$. TOC and TN in the eroded sediment were also determined in samples taken from the slurry-treated slopes. The majority of the experiments showed increases in the concentrations of TOC in the eroded sediment compared to the control slopes (Mann-Whitney, control vs. slurry, $p=<0.02$ for all experiments), with maximum values of up to $4.2 \%$. The experiments which did not generate high erosion rates had lower concentrations of $1.5 \%$ TOC. Concentrations of TOC in the eroded sediment samples generally decreased through time in most experiments, except when erosion rates where sustained through the experiments whence values also remained stable. TN concentrations of eroded sediment were greater than those in the control soil in only one experiment, however they were not significantly more (Mann-Whitney, control vs. slurry, $p=0.179)$. Overall, these data confirm that the elemental analyses alone do not provide a robust method to trace the transport of slurry-derived particulates.

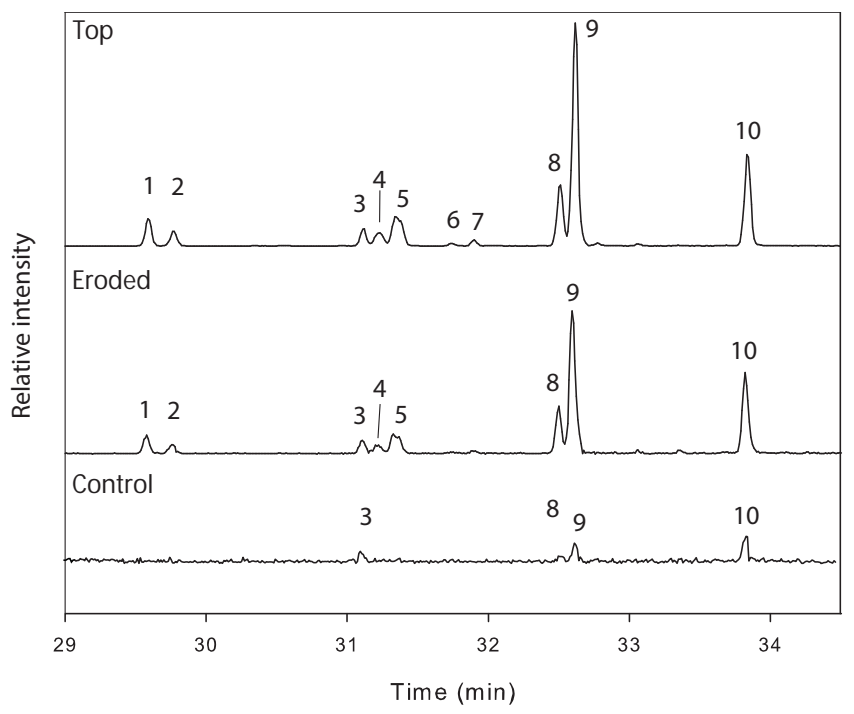

Figure 9. Partial chromatogram $(m / z=215)$ showing examples of characteristic hydrolysed lipid extracts from the top section of the soil slope, the eroded sediment (taken from the $10^{\circ}, 60 \mathrm{mmh}^{-1}$ experiment) and the control soil. Where $1=$ coprostanol, $2=$ epicoprostanol, $3=5 \alpha$-cholestanol, $4=5 \beta$ campestanol, $5=5 \beta$-epicampestanol, $6=24$-ethyl-campestanol, $7=24$-ethyl- $5 \beta$-cholestan- $3 \alpha$-ol, $\quad 8=5 \beta$-stigmastanol, $\quad 9=5 \beta$ epistigmstanol, $10=5 \alpha$-stigmastanol.

\subsubsection{Lipid analyses on eroded sediment and soil cores}

Figure 9 shows example partial chromatograms for a soil core from the top area of the slope, eroded sediment and the control soil. These data clearly illustrate the dominance of the $5 \beta$-stanols in the slurry-treated samples relative to the control soil. The concentration of $5 \beta$-stanols, a robust biomarker for slurry-derived IOM, in the slurry was $12982 \mathrm{ng} \mathrm{g}^{-1}$ compared with an average of $67.7 \mathrm{ng} \mathrm{g}^{-1}$ in the control soil. The soil cores taken from the slurry application area were significantly enriched with concentrations averaging $2850 \mathrm{ng} \mathrm{g}^{-1}$ (Mann-Whitney, control vs. slurry, $p=0.010$ ). Generally, the $5 \beta$-stanol concentrations in the soil cores decreased exponentially with distance downslope, with average concentrations at the bottom of the slope of $84 \mathrm{ngg}^{-1}$ which were not significantly different from the control soil (MannWhitney, control vs. slurry, $p=0.343$ ). The average concentration of the eroded sediment was $2040 \mathrm{ng} \mathrm{g}^{-1}$ which was also significantly enriched compared with the control soil (Mann-Whitney, control vs. slurry, $p=0.010$ ). Figure 10 shows the changes in the concentration of $5 \beta$-stanols in the soil cores in the downslope direction after each individual experiment. Some of the experiments showed increases in the concentrations of soil core $5 \beta$-stanols at the bottom of the slope, which suggests that deposition of slurry-derived IOM was occurring close to the slope outlet. The error bars in Fig. 10 represent the range of values from the three soil cores taken horizontally at each distance downslope. In some loca- 

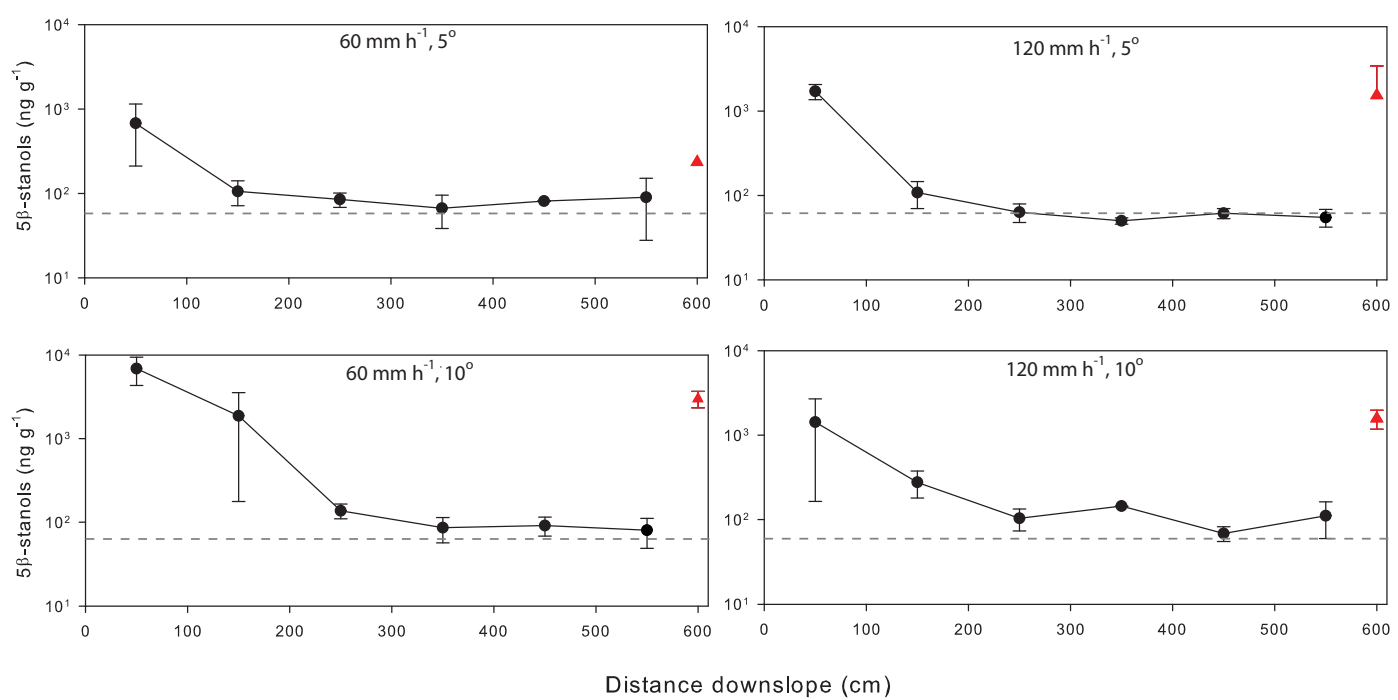

Figure 10. Plots showing the change in average concentration of $5 \beta$-stanols in soil cores downslope for each of the slurry-treated experiments. The dashed line shows the mean concentration in the control soil, and the triangles represent the average concentrations in the eroded sediment.

tions the range of concentrations was large, possibly due to preferential surface runoff pathways which distributed sediment laterally across the slope as well as downslope.

In addition to absolute concentrations the ratio between $5 \beta$ - (slurry-derived) and $5 \alpha$ - (soil-derived) stanols was calculated in order to assess the contribution of slurry-derived IOM versus native soil IOM in the soil cores (data not shown). Results showed a spatial pattern in the distribution of the ratio of $5 \beta-: 5 \alpha$-stanols in the soil across the slope surface for each experiment, exhibiting an exponential decline in $5 \beta-: 5 \alpha$-stanols ratio in the downslope direction from where slurry was applied. The main difference between the experiments was in the variability of stanol ratios, which was a function of slope gradient. The standard deviation and variance of the stanol ratios was calculated for each experiment (not including the top of the slope where the slurry was initially applied) in order to assess the variation in transported slurry-derived material between experiments (Table 2). The analysis showed that increasing slope gradient resulted in an increase in the standard deviation of the ratios in soil cores across the slope suggesting that surface runoff at lower gradients was flowing more evenly over the soil surface compared to the steeper slopes which may have exhibited more preferential flow routing.

The concentrations of $5 \beta$-stanols were also quantified in the sediment eroded from the slope during each experiment. In order to obtain an adequate sample of sediment for $5 \beta$ stanol analysis, the eroded sediment samples were combined into three time segments, representing the beginning, middle, and end of the rainfall simulation (see Table 3 for the experimental time covered by each composite sample). As the sediment flux from the $5^{\circ}, 60 \mathrm{~mm} \mathrm{~h}^{-1}$ experiment was relatively low only one analysis was possible which represented
Table 2. Spatial variability in the ratios of $5 \beta: 5 \alpha$-stanols in soil cores across the slope for each experiment (excluding samples taken in the slurry application area).

\begin{tabular}{llcc}
\hline & & Standard deviation & Variance \\
\hline \multirow{2}{*}{$60 \mathrm{~mm} \mathrm{~h}^{-1}$} & $5^{\circ}$ & 0.14 & 0.02 \\
& $10^{\circ}$ & 0.79 & 0.62 \\
\hline \multirow{2}{*}{$120 \mathrm{~mm} \mathrm{~h}^{-1}$} & $5^{\circ}$ & 0.39 & 0.15 \\
& $10^{\circ}$ & 0.42 & 0.17 \\
\hline
\end{tabular}

the entire event. The average concentrations of $5 \beta$-stanols are shown in Fig. 9 and the temporal variations in concentrations are shown in Table 3. The lowest concentration of $5 \beta$-stanols was recorded in the eroded sediment from the experiment with the lowest volume of surface runoff, suggesting that transport of slurry-derived POM was therefore limited, and therefore reflected in the low sediment yield under these conditions. Experiments with higher volumes of surface runoff resulted in an increase in the $5 \beta$-stanol concentrations by up to a factor of 10 . Increasing rainfall intensity appeared to have little effect on the concentrations of $5 \beta$ stanols exported at the beginning of the rainfall simulations at a slope gradient of $5^{\circ}$. However, increasing slope gradient resulted in a rapid decrease in concentrations during the middle and end of the simulations. The supply of slurry-derived material was exported from the slope faster at steeper slope gradients due to the increased sediment flux, as shown in Table 2. Slope gradient had a larger impact on the total transport of $5 \beta$-stanols than the increase in rainfall intensity, due to an exponential increase in sediment yield. 
Table 3. Concentrations of $5 \beta$-stanols in the eroded sediment (dry weight basis) through time and the total exported mass throughout the experiment.

\begin{tabular}{|c|c|c|c|c|c|c|c|c|c|c|}
\hline & \multicolumn{5}{|c|}{$60 \mathrm{mmh}^{-1}$} & \multicolumn{5}{|c|}{$120 \mathrm{~mm} \mathrm{~h}^{-1}$} \\
\hline & \multirow[b]{2}{*}{$\begin{array}{l}\text { Time } \\
(\min )\end{array}$} & \multicolumn{2}{|c|}{$5^{\circ}$} & \multicolumn{2}{|c|}{$10^{\circ}$} & \multirow[b]{2}{*}{$\begin{array}{l}\text { Time } \\
(\min )\end{array}$} & \multicolumn{2}{|c|}{$5^{\circ}$} & \multicolumn{2}{|c|}{$10^{\circ}$} \\
\hline & & $\begin{array}{c}\text { Conc. } \\
\left(\operatorname{ngg}^{-1}\right)\end{array}$ & $\begin{array}{c}\text { Mass } \\
(\mu \mathrm{g})\end{array}$ & $\begin{array}{c}\text { Conc. } \\
\left(\operatorname{ngg}^{-1}\right)\end{array}$ & $\begin{array}{c}\text { Mass } \\
(\mu g)\end{array}$ & & $\begin{array}{c}\text { Conc. } \\
\left(\mathrm{ngg}^{-1}\right)\end{array}$ & $\begin{array}{c}\text { Mass } \\
(\mu \mathrm{g})\end{array}$ & $\begin{array}{c}\text { Conc. } \\
\left(\operatorname{ngg}^{-1}\right)\end{array}$ & $\begin{array}{c}\text { Mass } \\
(\mu \mathrm{g})\end{array}$ \\
\hline Beginning & $0-30$ & $351^{*}$ & 3.3 & 3477.2 & 666.7 & $0-20$ & 306.1 & 3611.0 & 2024.4 & 6912.5 \\
\hline Middle & $30-60$ & - & - & 3005.2 & 716.5 & $20-35$ & 545.0 & 1032.2 & 1426.0 & 9274.2 \\
\hline End & $60-100$ & - & - & 2533.1 & 734.0 & $35-50$ & 360.7 & 417.1 & 1280.2 & 6725.3 \\
\hline Total & & & 3.3 & & 2123 & & & 5060 & & 22912 \\
\hline
\end{tabular}

* This experiment only had one time interval due to the lack of sediment to analyse.

\section{Discussion}

This study used a series of six controlled laboratory experiments to assess the effect of slope gradient and rainfall intensity on the transport of slurry-derived compounds. This work also provided an extension to the proof of concept developed in Lloyd et al. (2012) for using fluorescence and $5 \beta$-stanols simultaneously to trace both the vertical and lateral transport of slurry-derived material in both dissolved and particulate forms.

\subsection{Role of slope gradient and rainfall intensity on transport slurry-derived compounds}

It was hypothesised that changes in slope gradient and rainfall intensity would alter the relative partitioning of slope flow pathways and erosion rates which would in turn exert a strong control on the flux and yield of slurry-derived compounds. The impact of these variables on slurry transport can be described by two main hydrologically driven scenarios.

(1) Overland flow dominated systems, which typically occur on steep slopes and/or high rainfall intensities. High overland flow rates typically result in high erosion rates and the combination of the two enhances transport of slurryderived compounds via surface pathways (dissolved in runoff and bound to eroded sediment), which are rapid and interact directly with the source of applied slurry material. The concentration of the dissolved components depends on the volume of runoff produced. Higher intensity rainfall events generally transported the overall largest load of slurry-derived dissolved material but the concentrations were lower. This result is supported by Delpla et al. (2011), who showed in a field study that it was the highest intensity rainfall events which generated overland flow that yielded the highest DOC export prior to cattle slurry application. Dissolved components of slurry which have been diluted by increased volumes of discharge will have a lower immediate impact on stream ecology. However, the larger total load exported during highintensity storms will result in greater total losses of nutrients from the soil and could result in pressures on receiving waters, such as increased biological oxygen demand (BOD). It is estimated that input of cattle slurry can produce a BOD of between 10000 and $30000 \mathrm{mg} \mathrm{L}^{-1}$, leading to reduced oxygen levels and ultimately the death of aquatic life (Khaleel et al., 1980; Baker, 2002a; Foy and Kirk, 1995).

The concentrations of slurry-derived particulates were controlled primarily by the slope gradient, however, the overall load increased substantially (between 1 and 3 orders of magnitude) with increased rainfall intensity due to the increased sediment transport by overland flow. This is supported by Michaelides et al. (2012) who showed the importance of erosion events on landscape nutrient loss. Although small amounts of subsurface and percolated flow occurred at the higher rainfall intensity, they do not play a key role in the transport of slurry-derived particulates. In the overland flow dominated experiment $\left(10^{\circ}, 120 \mathrm{~mm} \mathrm{~h}^{-1}\right)$ over $4 \mathrm{~kg}$ of sediment was exported (over an area of $15 \mathrm{~m}^{2}$ ), containing $2.3 \mathrm{mg}$ of $5 \beta$-stanols in under $1 \mathrm{~h}$ of rainfall, compared with a total of $\sim 9.7 \mathrm{mg}$ of $5 \beta$-stanols added to the soil as slurry before the experiment. The experiment that generated less than $1 \%$ of its discharge by overland flow $\left(5^{\circ}, 60 \mathrm{~mm} \mathrm{~h}^{-1}\right)$ eroded just $14 \mathrm{~g}$ of sediment ( $3 \mu \mathrm{g} 5 \beta$-stanols) during the experiment. Due to the rapid movement of slurry-derived material in this overland flow scenario there is little time for the slurry-derived components to transform, for example the nitrification of $\mathrm{NH}_{4}^{+}$to $\mathrm{NO}_{2}^{-}$and $\mathrm{NO}_{3}^{-}$or the mineralisation of the organic fraction to more labile inorganic forms. As a result, over short timescales after slurry application, the transported fractions of slurry tended to reflect the original slurry composition. This result can also be expected to be observed in a field scenario where material is rapidly transported from an area of slurry application.

(2) A predominance of vertical, percolated flow, which typically occur due to low slope gradients coupled with lower rainfall intensities. Under this regime, the export of slurryderived material is mainly in dissolved form and the flux tends to be higher directly beneath, or close to the application area. The timing of the dissolved flux also tends to be slower 
compared with an overland flow dominated regime due to the time needed for percolation to occur through the soil matrix (Kirkby, 1969). If surface runoff develops during a rainfall event due to saturation excess, some dissolved slurryderived material will be transported towards the slope outlet, but the concentrations will be lower than in an overland flowdominated system. This is because a large proportion of the dissolved slurry-derived material will have already infiltrated into the subsurface in the time taken for the soil to saturate and initiate overland flow. Buda and DeWalle (2009) showed that larger storm events which caused saturation-excess overland were responsible for flushing stored nutrients via shallow subsurface pathways. In addition, overland flow transports sediment-bound components which have been shown to remain in the top layers of the soil regardless of the volume of infiltration (Lloyd et al., 2012). Under systems dominated by infiltration and vertical percolated pathways there is a potential longer-term contamination threat to surface sediment and groundwater. The percolated slurry-derived material will remain in the deeper soil layers and be available for leaching during subsequent rainfall events and potentially assimilated by the microbial community. The $\mathrm{NH}_{4}^{+}$is subject to nitrification resulting in increased $\mathrm{NO}_{3}^{-}$and the organic components will be mineralised over time to add further $\mathrm{NO}_{3}^{-}$ to the inorganic nutrient pool. This provides a large supply of accessible nutrients for plant growth, however, if there is a surplus after plant uptake or it is leached below the root zone then these nutrients can be transported into groundwater or via deeper subsurface flows to water courses (Vitousek et al., 2009; Burow et al., 2010; Melo et al., 2012; Morari et al., 2012), thereby posing a longer-term contamination threat.

Overall, we conclude that the controls on the transport of slurry-derived material (soluble and insoluble) are complex and that flow pathway partitioning induced by slope gradient, rainfall intensity, and duration play important roles. Rainfall is an important transport driver for both dissolved and particulate components. Raindrop action is a well-known mechanism for detaching and mobilising sediment particles, but it can also act to eject soil water and therefore release solute into runoff (Gao et al., 2004). In addition, when the rainfall event acts to saturate the soil profile diffusion will occur, allowing diffusion to liberate chemicals from the soil matrix. Experiments run by Gao et al. (2004) showed that at the beginning of a rain event raindrop impact was the main mechanism for liberating solute, followed by diffusion at the latter stages of the storm. In addition, research has also shown that storms which have variable rainfall intensities can increase the transport of solute in surface runoff and via preferential subsurface routes (Zhang et al., 1997; Malone et al., 2004).

\subsection{Use of a combined tracer approach to monitor the transport of slurry-derived material}

This study also aimed to test efficacy of the use of a combined biomarker approach to monitor the vertical and lateral transport of dissolved and particulate slurry fractions. In the current study the transport of dissolved slurry-derived material within different flow pathways was monitored using $\mathrm{NH}_{4}^{+}$concentrations and fluorescence. Over short timescales (hours) $\mathrm{NH}_{4}^{+}$concentrations can provide useful information regarding the timing and spatial patterns of movement of dissolved slurry compounds. Field data have shown that areas which have high N-loading, such as those treated with slurry, could receive $\mathrm{N}$ at a higher rate than can be incorporated into the organic fraction, resulting in inorganic-N, especially $\mathrm{NH}_{4}^{+}$becoming available for rapid transfer to watercourses, often via preferential flow pathways (Heathwaite and Johnes, 1996). However, within days the signal will degrade due to nitrification of $\mathrm{NH}_{4}^{+}$into $\mathrm{NO}_{3}^{-}$, which would be difficult to distinguish from soil-derived $\mathrm{N}$, without the use of isotopic enrichment additions.

Fluorescence spectroscopy was shown by Lloyd et al. (2012) to be a robust tracer of DOM, which was slurryderived over short timescales and in relatively small-scale soil columns. However when this technique was applied to the more complex 3-D laboratory system the results were not as clear. While the fluorescence intensity at an excitation at $270 \mathrm{~nm}$ was not significantly different between the slurry-treated and control experiments, using the ratio between 270 and 360 intensities provided a detectable signal. The ratio was able to identify smaller changes in the fluorescence spectra which were not possible using the 270 fluorescence intensity alone. The fluorescence intensities recorded from the TRACE experiments were several orders of magnitude lower than those from the soil column experiments (Lloyd et al., 2012), due to the larger volume of rainfall added in the TRACE experiments which resulted in a significantly smaller slurry : soil ratio. The slurry was only applied to the top $1 \mathrm{~m}$ strip of the slope and therefore the signal was rapidly diluted both by the rainfall and the additional signal from the soil-derived DOM. Furthermore, the $270: 360$ ratio of the slurry was calculated at 1.7 , which is lower than the range cited in the literature $(\sim 2-5)$ for cattle slurries (Baker, 2002a). This could be because when the slurry was collected (during April 2008), it had been a very wet spring and as a result the farm slurry store had received higher than average volumes of rainwater, potentially diluting the slurry before application.

Fluorescence spectroscopy has been shown previously to be a powerful technique for characterising DOM, even in very dilute samples (e.g. Barker et al., 2009; Birdwell and Engel, 2010). However, the signal was more difficult to detect in this case because the soil-derived DOM swamped the slurry signal, making it difficult to resolve the two sources. This problem was exaggerated in the case of the higher in- 
tensity rainfall experiments due to the additional water being transported with the slurry. If a larger section of the slope had been treated with slurry then it is more likely that the signal could have been seen. Naden et al. (2010) showed that drainage water from field lysimeters treated with slurry could be distinguished from control experiments, even though only a small proportion of the applied slurry was thought to have been leached from the system. However, work by Old et al. (2012) showed that fluorescence differences could not be identified in storm runoff samples after an application of cattle slurry to undrained plots. The authors suggest that this was due to rapid absorption or microbially mediated immobilisation of the slurry material in the soil matrix. Baker (2002b) showed that river water samples from the UK exhibited $270: 360$ ratios of $0.37 \pm 0.41(n=242)$, suggesting that cattle slurries may be difficult to detect once they are diluted compared to the background river fluorescence. However, Baker (2002b) concludes that the techniques would be able to detect cattle slurry inputs from large point sources, such as slurry tank failures.

The particulate fraction was investigated using bulk elemental analysis, followed by quantifying the $5 \beta$-stanol concentrations. Soil analyses of bulk $\mathrm{C}$ and $\mathrm{N}$ were found to be generally ineffective at tracing transport pathways of slurryderived POM. The eroded sediments from all of the experiments showed increases in TOC and TN values compared with the control but the source of origin of the TOC and TN cannot be identified (i.e. slurry or soil). The use of the specific biomarkers $5 \beta$-stanols provides more robust information about the transport of slurry-derived particulates as they have been shown to be an unequivocal tracer of ruminant slurry (Bull et al., 2002; Elhmmali et al., 2000; Evershed et al., 1997; Nash et al., 2005). The concentration of the $5 \beta$-stigmastanol in the slurry used in this study was lower than other published values, with an average concentration of $\sim 12 \mu \mathrm{gg}^{-1}$ of freeze-dried slurry, compared with $\sim 46 \mu \mathrm{g} \mathrm{g}^{-1}$ (Leeming et al., 1996). However, there was still a large difference between the slurry concentration and the initial soil, so this did not cause any issues for using the biomarker as a tracer. On the other hand, the ratios of the $5 \beta: 5 \alpha$-stanols determined in the current study were very similar to other published values, where ratios from soil cores taken from the slurry application area ranged from 2.4 to 2.9, compared with an average ratio of $\sim 2$ measured in cow manures (Evershed et al., 1997). Data collected here further illustrate that $5 \beta$-stanols are a robust tracer of slurry-derived IOM, and therefore could be used to monitor the transport of particulate forms of slurry.

Overall, the results show that using a combination of tracers and biomarkers for both soluble and insoluble fractions can be very effective for tracing the movement of slurry via multiple transport pathways. This work provides a proof of concept that the methodology works in larger and more complex controlled laboratory systems. While elements of this type of methodology have been tested in field scenarios (e.g. Naden et al., 2010; Granger et al., 2010; Evershed et al., 1997; Bull et al., 1998; Nash et al., 2005), there is still a need to test this combined tracer approach in a larger field study.

\section{Conclusions}

This work has provided important and new insights into flow partitioning across a range of controlled hillslope and rainfall scenarios and has allowed quantification of the impact this has on the transport of slurry-derived compounds. Results indicate that the dissolved components of slurry-derived material (traced using $\mathrm{NH}_{4}^{+}$and the ratio between $270: 360$ fluorescence intensities) were transported rapidly through the soil system, while the predominant pathway depended on the flow partitioning. When the conditions favoured surface runoff, i.e. high slope gradients and/or high rainfall intensities, larger quantities of slurry-derived material were moved in the surface and subsurface flow pathways. These shallow flow pathways transport water more rapidly to the slope outlet compared with vertical percolated flow which travelled slowly through the soil matrix. The movement of slurryderived particulates (traced using $5 \beta$-stanols) is driven exclusively by the erosion rates on the slope.

Rainfall events which produced flashy hydrological responses, resulting in large quantities of surface runoff, were likely to move sediment and also flush dissolved components of slurry-derived material from the slope, increasing the contamination risk. Rainfall events which produced slower hydrological responses were dominated by vertical percolated flows removing less sediment-associated material, but produced leachate which could contaminate deeper soil layers, and potentially groundwater, over a more prolonged period.

This work has also provided one of the first examples of using multiple biomarkers to assess the effects of slope gradient and rainfall intensity on the movement of slurry-derived OM. The results have shown that this approach can be successfully applied to more complex 3-D systems (than simple soil columns) and can yield valuable data about the interactions between slurry and the soil-water system. Overall, this research provides new insights into the partitioning of slurryderived material when applied to an unvegetated slope and the transport mechanisms by which contamination risks are created.

Acknowledgements. This work was funded by NERC Studentship (NE/F008856/1) to C. E. M. Lloyd.

Edited by: Y. Kuzyakov 


\section{References}

Aksoy, H., Unal, N. E., Cokgor, S., Gedikli, A., Yoon, J., Koca, K., Inci, S. B., and Eris, E.: A rainfall simulator for laboratory-scale assessment of rainfall-runoff-sediment transport processes over a two-dimensional flume, Catena, 98, 63-72, doi:10.1016/j.catena.2012.06.009, 2012.

Asam, Z. U., Kaila, A., Nieminen, M., Sarkkola, S., O’Driscoll, C., O'Connor, M., Sana, A., Rodgers, M., and Xiao, L. W.: Assessment of phosphorus retention efficiency of blanket peat buffer areas using a laboratory flume approach, Ecol. Eng., 49, 160-169, doi:10.1016/j.ecoleng.2012.08.020, 2012.

Baker, A.: Spectrophotometric discrimination of river dissolved organic matter, Hydrol. Process., 16, 3203-3213, doi:10.1002/hyp.1097, 2002a.

Baker, A.: Fluorescence properties of some farm wastes: implications for water quality monitoring, Water Res., 36, 189-195, 2002b.

Barker, J. D., Sharp, M. J., and Turner, R. J.: Using synchronous fluorescence spectroscopy and principal components analysis to monitor dissolved organic matter dynamics in a glacier system, Hydrol. Process., 23, 1487-1500, doi:10.1002/hyp.7274, 2009.

Berthelot, M. P. E.: Berthelot's reaction mechanism, Report Chim Appl., 384, p. 284, 1859.

Birdwell, J. E. and Engel, A. S.: Characterization of dissolved organic matter in cave and spring waters using UV-Vis absorbance and fluorescence spectroscopy, Org. Geochem., 41, 270-280, doi:10.1016/j.orggeochem.2009.11.002, 2010.

Blanchard, P. E. and Lerch, R. N.: Watershed vulnerability to losses of agricultural chemicals: interactions of chemistry, hydrology, and land-use, Environ. Sci. Technol., 34, 3315-3322, doi:10.1021/es991115+, 2000.

Buda, A. R. and DeWalle, D. R.: Dynamics of stream nitrate sources and flow pathways during stormflows on urban, forest and agricultural watersheds in central Pennsylvania, USA, Hydrol. Process., 23, 3292-3305, doi:10.1002/hyp.7423, 2009.

Bull, I. D., Van Bergen, P. F., Poulton, P. R., and Evershed, R. P.: Organic geochemical studies of soils from the Rothamsted Classical Experiments - II, Soils from the Hoosfield Spring Barley Experiment treated with different quantities of manure, Org. Geochem., 28, 11-26, 1998.

Bull, I. D., Lockheart, M. J., Elhmmali, M. M., Roberts, D. J., and Evershed, R. P.: The origin of faeces by means of biomarker detection, Environ. Int., 27, 647-654, 2002.

Burow, K. R., Nolan, B. T., Rupert, M. G., and Dubrovsky, N. M.: Nitrate in groundwater of the United States, 1991-2003, Environ. Sci. Technol., 44, 4988-4997, doi:10.1021/es100546y, 2010.

Chadwick, D. R. and Chen, S.: Manures, in: Agriculature, Hydrology and Water Quality, edited by: Haygarth, P. M. and C., J. S., CAB International, Wallingford, UK, 57-82, 2003.

Chambers, B. J., Smith, K. A., and Pain, B. F.: Strategies to encourage better use of nitrogen in animal manures, Soil Use Manage., $16,157-161,2000$.

Coelho, B. B., Lapen, D., Murray, R., Topp, E., Bruin, A., and Khan, B.: Nitrogen loading to offsite waters from liquid swine manure application under different drainage and tillage practices, Agr. Water Manage., 104, 40-50, doi:10.1016/j.agwat.2011.11.014, 2012.

CSF Evidence Team: Catchment Sensitive Farming ECSFDI Phase 1 \& 2, Full Evaluation Report, London, 2011.
Delconte, C. A., Sacchi, E., Racchetti, E., Bartoli, M., Mas-Pla, J., and Re, V.: Nitrogen inputs to a river course in a heavily impacted watershed: a combined hydrochemical and isotopic evaluation (Oglio River Basin, N Italy), Sci. Total Environ., 466, 924-938, doi:10.1016/j.scitotenv.2013.07.092, 2014.

Delpla, I., Baures, E., Jung, A.-V., and Thomas, O.: Impacts of rainfall events on runoff water quality in an agricultural environment in temperate areas, Sci. Total Environ., 409, 1683-1688, doi:10.1016/j.scitotenv.2011.01.033, 2011.

Diaz, R. J. and Rosenberg, R.: Spreading dead zones and consequences for marine ecosystems, Science, 321, 926-929, doi:10.1126/science.1156401, 2008.

Dungait, J. A. J., Cardenas, L. M., Blackwell, M. S. A., Wu, L., Withers, P. J. A., Chadwick, D. R., Bol, R., Murray, P. J., Macdonald, A. J., Whitmore, A. P., and Goulding, K. W. T.: Advances in the understanding of nutrient dynamics and management in UK agriculture, Sci. Total Environ., 434, 39-50, doi:10.1016/j.scitotenv.2012.04.029, 2012.

Durand, P., Breuer, L., and Johnes, P. J.: Nitrogen process in aquatic systems, in: The European Nitrogen Assessment: Sources, Effects and Policy Perspectives, edited by: Sutton, M. A., Howard, C. M., Erisman, J. W., Billen, G., Bleeker, A., Grennfelt, P., van Grinsven, H., and Grizzetti, B., Cambridge University Press, Cambridge, 126-146, 2011.

Eastman, M., Gollamudi, A., Stampfli, N., Madramootoo, C. A., and Sarangi, A.: Comparative evaluation of phosphorus losses from subsurface and naturally drained agricultural fields in the Pike River watershed of Quebec, Canada, Agr. Water Manage., 97, 596-604, doi:10.1016/j.agwat.2009.11.010, 2010.

Edwards, A. C., Watson, H. A., and Cook, Y. E. M.: Source strengths, transport pathways and delivery mechanisms of nutrients, suspended solids and coliforms within a small agricultural headwater catchment, Sci. Total Environ., 434, 123-129, doi:10.1016/j.scitotenv.2011.10.055, 2012.

Elhmmali, M. M., Roberts, D. J., and Evershed, R. P.: Combined analysis of bile acids and sterols/stanols from riverine particulates to assess sewage discharges and other fecal sources, Environ. Sci. Technol., 34, 39-46, 2000.

Evans, D. J. and Johnes, P. J.: Physico-chemical controls on phosphorus cycling in two lowland streams. Part 1 - The water column, Sci. Total Environ., 329, 145-163, 2004.

Evershed, R. P., Bethell, P. H., Reynolds, P. J., and Walsh, N. J.: $5 \beta$ Stigmastanol and Related $5 \beta$-Stanols as Biomarkers of Manuring: Analysis of Modern Experimental Material and Assessment of the Archaeological Potential, J. Archaeol. Sci., 24, 485-495, doi:10.1006/jasc.1996.0132, 1997.

Foy, R. H. and Kirk, M.: Agriculture and water-quality - a regional study, J. Chart. Inst. Water E., 9, 247-256, 1995.

Gao, B., Walter, M. T., Steenhuis, T. S., Hogarth, W. L., and Parlange, J. Y.: Rainfall induced chemical transport from soil to runoff: theory and experiments, J. Hydrol., 295, 291-304, doi:10.1016/j.jhydrol.2004.03.026, 2004.

Granger, S. J., Bol, R., Dixon, L., Naden, P. S., Old, G. H., Marsh, J. K., Bilotta, G., Brazier, R., White, S. M., and Haygarth, P. M.: Assessing multiple novel tracers to improve the understanding of the contribution of agricultural farm waste to diffuse water pollution, J. Environ. Monitor., 12, 1159-1169, doi:10.1039/b915929k, 2010. 
Guo, T., Wang, Q., Li, D., and Wu, L.: Sediment and solute transport on soil slope under simultaneous influence of rainfall impact and scouring flow, Hydrol. Process., 24, 1446-1454, doi:10.1002/hyp.7605, 2010.

Haygarth, P. M., Wood, F. L., Heathwaite, A. L., and Butler, P. J.: Phosphorus dynamics observed through increasing scales in a nested headwater-to-river channel study, Sci. Total Environ., 344, 83-106, 2005.

Haygarth, P. M., Page, T. J. C., Beven, K. J., Freer, J., Joynes, A., Butler, P., Wood, G. A., and Owens, P. N.: Scaling up the phosphorus signal from soil hillslopes to headwater catchments, Freshwater Biol., 57, 7-25, doi:10.1111/j.13652427.2012.02748.x, 2012.

Heathwaite, A. L. and Johnes, P. J.: Contribution of nitrogen species and phosphorus fractions to stream water quality in agricultural catchments, Hydrol. Process., 10, 971-983, doi:10.1002/(sici)1099-1085(199607)10:7<971::aidhyp351>3.0.co;2-n, 1996.

HELCOM: Eutrophication in the Baltic Sea: An integrated assessment of the effects of nutrient enrichment in the Baltic Sea Region, Baltic Marine Environment Protection Commission Helsinki, Finland, 2009.

Hudson, N., Baker, A., and Reynolds, D.: Fluorescence analysis of dissolved organic matter in natural, waste and polluted waters a review, River Res. Appl., 23, 631-649, doi:10.1002/rra.1005, 2007.

Johnes, P. J. and Burt, T. P.: Water-quality trends in the windrush catchment - nitrogen speciation and sediment interactions, in: Sediment and Stream Water Quality in a Changing Environment: Trends and Explanation, IAHS Publications, Wallingford, UK, 203, 349-357, 1991.

Jones, D. L., Healey, J. R., Willett, V. B., Farrar, J. F., and Hodge, A.: Dissolved organic nitrogen uptake by plants - an important $\mathrm{N}$ uptake pathway?, Soil Biol. Biochem., 37, 413-423, doi:10.1016/j.soilbio.2004.08.008, 2005.

Khaleel, R., Reddy, K. R., and Overcash, M. R.: Transport of potential pollutants in runoff water from land areas receiving animal wastes - a review, Water Res., 14, 421-436, 1980.

Kirkby, M. J.: Infiltration, throughflow and overland flow, in: Water, Earth and Man a Synthesis of Hydrology Geomorphology and Socio-Economic Geography, edited by: Chorley, R. J., Methuen and Co. Ltd., London, UK, 215-227, 1969.

Lakowicz, J. R.: Principles of Fluorescence Spectroscopy, Plenum, New York, 1983.

Leeming, R., Ball, A., Ashbolt, N., and Nichols, P.: Using faecal sterols from humans and animals to distinguish faecal pollution in receiving waters, Water Res., 30, 2893-2900, 1996.

Lloyd, C. E. M., Michaelides, K., Chadwick, D. R., Dungait, J. A. J., and Evershed, R. P.: Tracing the flowdriven vertical transport of livestock-derived organic matter through soil using biomarkers, Org. Geochem., 43, 56-66, doi:10.1016/j.orggeochem.2011.11.001, 2012.

Malone, R. W., Weatherington-Rice, J., Shipitalo, M. J., Fausey, N., Ma, L. W., Ahuja, L. R., Wauchope, R. D., and Ma, Q. L.: Herbicide leaching as affected by macropore flow and within-storm rainfall intensity variation: a RZWQM simulation, Pest Manag. Sci., 60, 277-285, doi:10.1002/ps.791, 2004.
Melo, A., Pinto, E., Aguiar, A., Mansilha, C., Pinho, O., and Ferreira, I. M. P. L. V. O.: Impact of intensive horticulture practices on groundwater content of nitrates, sodium, potassium, and pesticides, Environ. Monit. Assess., 184, 4539-4551, doi:10.1007/s10661-011-2283-4, 2012.

Michaelides, K., Ibraim, I., Nord, G., and Esteves, M.: Tracing sediment redistribution across a break in slope using rare earth elements, Earth Surf. Proc. Land., 35, 575-587, doi:10.1002/esp.1956, 2010.

Michaelides, K., Lister, D., Wainwright, J., and Parsons, A .J.: Linking runoff and erosion dynamics to nutrient fluxes in a degrading dryland landscape, J. Geophys. Res., 117, G00N15, doi:10.1029/2012JG002071, 2012.

Mitsch, W. J., Day, J. W., Gilliam, J. W., Groffman, P. M., Hey, D. L., Randall, G. W., and Wang, N. M.: Reducing nitrogen loading to the Gulf of Mexico from the Mississippi River Basin: strategies to counter a persistent ecological problem, Bioscience, 51, 373-388, doi:10.1641/00063568(2001)051[0373:rnlttg]2.0.co;2, 2001.

Montenegro, A. A. A., Abrantes, J. R. C. B., de Lima, J. L. M. P., Singh, V. P., and Santos, T. E. M.: Impact of mulching on soil and water dynamics under intermittent simulated rainfall, Catena, 109, 139-149, doi:10.1016/j.catena.2013.03.018, 2013.

Morari, F., Lugato, E., Polese, R., Berti, A., and Giardini, L.: Nitrate concentrations in groundwater under contrasting agricultural management practices in the low plains of Italy, Agr. Ecosyst. Environ., 147, 47-56, doi:10.1016/j.agee.2011.03.001, 2012.

Naden, P. S., Old, G. H., Eliot-Laize, C., Granger, S. J., Hawkins, J. M. B., Bol, R., and Haygarth, P.: Assessment of natural fluorescence as a tracer of diffuse agricultural pollution from slurry spreading on intensely-farmed grasslands, Water Res., 44, 17011712, 2010.

Nash, D., Leeming, R., Clemow, L., Hannah, M., Halliwell, D., and Allen, D.: Quantitative determination of sterols and other alcohols in overland flow from grazing land and possible source materials, Water Res., 39, 2964-2978, doi:10.1016/j.watres.2005.04.063, 2005.

Ohno, T.: Fluorescence inner-filtering correction for determining the humification index of dissolved organic matter, Environ. Sci. Technol., 36, 742-746, doi:10.1021/es0155276, 2002.

Old, G. H., Naden, P. S., Granger, S. J., Bilotta, G. S., Brazier, R. E., Macleod, C. J. A., Krueger, T., Bol, R., Hawkins, J. M. B., Haygarth, P., and Freer, J.: A novel application of natural fluorescence to understand the sources and transport pathways of pollutants from livestock farming in small headwater catchments, Sci. Total Environ., 417, 169-182, doi:10.1016/j.scitotenv.2011.12.013, 2012.

Osterman, L. E., Poore, R. Z., Swarzenski, P. W., Senn, D. B., and DiMarco, S. F.: The 20th-century development and expansion of Louisiana shelf hypoxia, Gulf of Mexico, Geo-Mar. Lett., 29, 405-414, doi:10.1007/s00367-009-0158-2, 2009.

Peukert, S., Griffith, B. A., Murray, P. J., Macleod, C. J. A., and Brazier, R. E.: Intensive management in grasslands causes diffuse water pollution at the farm scale, J. Environ. Qual., 43, 20092023, doi:10.2134/jeq2014.04.0193, 2014. 
Peuravuori, J., Koivikko, R., and Pihlaja, K.: Characterization. differentiation and classification of aquatic humic matter separated with different sorbents: synchronous scanning fluorescence spectroscopy, Water Res., 36, 4552-4562, 2002.

Pretty, J. N., Brett, C., Gee, D., Hine, R. E., Mason, C. F., Morison, J. I. L., Raven, H., Rayment, M. D., and van der Bijl, G.: An assessment of the total external costs of UK agriculture, Agr. Syst., 65, 113-136, doi:10.1016/s0308-521x(00)00031-7, 2000.

Quemada, M., Baranski, M., Nobel-de Lange, M. N. J., Vallejo, A., and Cooper, J. M.: Meta-analysis of strategies to control nitrate leaching in irrigated agricultural systems and their effects on crop yield, Agr. Ecosyst. Environ., 174, 1-10, doi:10.1016/j.agee.2013.04.018, 2013.

Rozemeijer, J. C. and Broers, H. P.: The groundwater contribution to surface water contamination in a region with intensive agricultural land use (Noord-Brabant, the Netherlands), Environ. Pollut., 148, 695-706, doi:10.1016/j.envpol.2007.01.028, 2007.

Sutton, M. A.: The European Nitrogen Assessment: Sources, Effects, and Policy Perspectives, Cambridge University Press, Cambridge, 612 pp., 2011. van Bergen, P. F., Bull, I. D., Poulton, P. R., and Evershed, R. P.: Organic geochemical studies of soils from the Rothamsted classical experiments - I. Total lipid extracts, solvent insoluble residues and humic acids from Broadbalk wilderness, Org. Geochem., 26, 117-135, 1997.

Vinolas, L. C., Healey, J. R., and Jones, D. L.: Kinetics of soil microbial uptake of free amino acids, Biol. Fert. Soils, 33, 67-74, doi:10.1007/s003740000291, 2001.

Vitousek, P. M., Naylor, R., Crews, T., David, M. B., Drinkwater, L. E., Holland, E., Johnes, P. J., Katzenberger, J., Martinelli, L. A., Matson, P. A., Nziguheba, G., Ojima, D., Palm, C. A., Robertson, G. P., Sanchez, P. A., Townsend, A. R., and Zhang, F. S.: Nutrient imbalances in agricultural development, Science, 324, 1519-1520, doi::10.1126/science.1170261, 2009.

Willett, V. B., Reynolds, B. A., Stevens, P. A., Ormerod, S. J., and Jones, D. L.: Dissolved organic nitrogen regulation in freshwaters, J. Environ. Qual., 33, 201-209, 2004.

Zhang, X. C., Norton, D., and Nearing, M. A.: Chemical transfer from soil solution to surface runoff, Water Resour. Res., 33, 809815, doi:10.1029/96wr03908, 1997. 